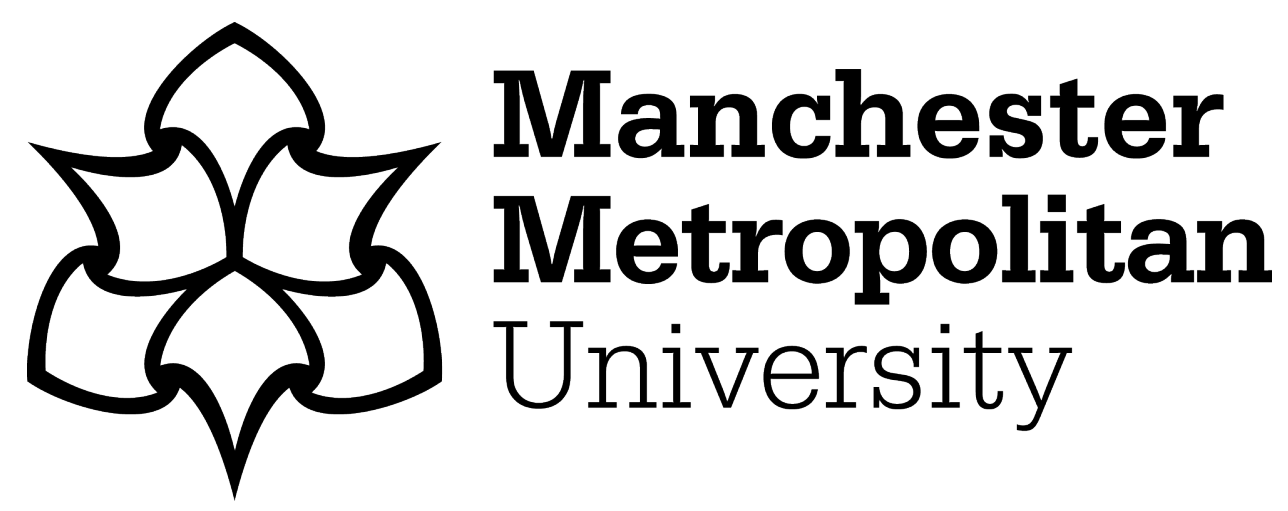

Bruff, I and Orth, K (2018) Framing the neoliberal canon: resisting the market myth via literary enquiry. Globalizations, 16 (3). pp. 245-259. ISSN 14747731

Downloaded from: https://e-space.mmu.ac.uk/621428/

Version: Accepted Version

Publisher: Taylor \& Francis (Routledge)

DOI: https://doi.org/10.1080/14747731.2018.1502489

Please cite the published version 


\title{
Framing the Neoliberal Canon: Resisting the Market Myth via Literary Enquiry
}

\author{
Ian Bruff (University of Manchester, UK) \& Kathryn Starnes \\ (Manchester Metropolitan University, UK)
}

\begin{abstract}
There is widespread recognition that neoliberal rhetoric about 'free markets' stands in considerable tension with 'really existing' neoliberalizing processes. However, the oft-utilized analytical distinction between 'pure' economic and political theory and 'messy' empirical developments takes for granted that neoliberalism, at its core, valorizes free markets. In contrast, the paper explores whether neoliberal intellectuals ever made such an argument. Using Friedrich Hayek and Milton Friedman as exemplars, our reading of canonical neoliberal texts focuses on author framing gestures, particular understandings of the term 'science', techniques of characterization, and constructions of epistemological legitimacy. This enables us to avoid the trap of assuming that these texts are about free markets and instead enquires into their constitution as literary artefacts. As such, we argue that the remaking of states and households rather than the promotion of free markets is at the core of neoliberalism. Our analysis has significant implications. For example, it means that authoritarian neoliberalism is not a departure from but actually more in line with the 'pure' neoliberal canon than in the past. Therefore, neoliberalism ought to be critiqued not for its rhetorical promotion of free markets but instead for seeking to reorganize societies in coercive, non-democratic and unequal ways. This also enables us to acknowledge that households are central to resistance to neoliberalism as well as to the neoliberal worldview itself.
\end{abstract}


Keywords: neoliberalism, states, households, markets, science, framing gestures

Correspondence: Ian Bruff, Department of Politics, Arthur Lewis Building, University of Manchester, M13 9PL, UK, ianbruff@gmail.com

\section{Introduction}

Despite widespread recognition that neoliberalism's rhetorical valorization of the 'free market' stands in considerable tension with 'really existing' neoliberalization processes, underlying respect for such claims persists. This is a consequence of the common focus on the contradictions between 'pure' neoliberal ideology and 'messy' empirical developments, whereby the role for the state and associated institutions is larger than anticipated in neoliberal ideology, leading to much attention being placed on studies of 'really existing neoliberalism' (Brenner \& Theodore, 2002; see also Harvey, 2005; Cahill, 2014). Therefore, while disagreements over whether neoliberalism is (for example) a set of ideas, a political programme, an ideological worldview or simply the discursive justification for the current phase of capitalism are important, the intellectual foundations of neoliberalism tend to be neglected. This is all the more significant when one considers the fact that the 'public intellectual' role played by key neoliberal thinkers such as Friedrich Hayek and Milton Friedman is often the focus of the analysis (for example, Hayek, 1944; Friedman, 1962). The literature overlooks the essential foundations for these political interventions, reflecting the de facto acceptance of 'in principle' claims about the 'free market'.

This paper contends that we need to re-examine the canonical texts of neoliberal thought in order to arrive at a more satisfactory understanding of neoliberalism, in theory and in practice. It is not enough, though, simply to re-read these publications. Instead, we demonstrate the benefits of re-examining the canon of neoliberal thought as literary artefacts rather than simply political or economic arguments. This reveals that free markets serve as a literary device that is at once a product of the text's constitution and what the text claims to objectively examine. ${ }^{1}$ This device allows the authors to maintain a claim to represent 'really existing' free markets in their writings while constituting free markets in an image that serves the aims of their narrative. The constitution of free markets as novel, even marvellous, depoliticizes the neoliberal project 
by making the project appear as objective representation of 'free market' reality rather than 'free markets' being instead understood as the product of constitutive authorial practices. There are further analytical implications, too. Most notably, our literary-theoretical approach reveals that neoliberalism has never been about free markets: the heavy intellectual burden borne in canonical neoliberal texts is actually the remaking of states and households in the name of the 'free market' image (for a similar approach, regarding Economics as a discipline, see Watson, 2017). Free markets are valorized as the ideal organizing principle for any capitalist society, but that is as far as it goes.

This means that scholarly, political and policy debates need substantial modification as a result. Many have argued that neoliberalism's economic and political dominance since the 1980s has been challenged in the last decade: witness the failure of pro-market policy paradigms regarding financial regulation, the bail-outs of financial institutions by national governments, and the state interventions to prop up economies for years afterwards (for example, deficit spending from 2008-10 and Quantitative Easing programmes thereafter). More recently, there has been the rise to prominence of a range of political leaders and parties (for example, Donald Trump, Left and Right populism in Europe) openly hostile to what are viewed as axioms of neoliberalism, such as free trade globally and free markets domestically. In contrast, we understand the current period of authoritarian neoliberalism as actually closer to the neoliberal vision than in the past. The notion that the last decade has witnessed developments that are contrary to neoliberal principles can make sense only if one understands neoliberalism to be about free markets, which we reject (see also Bruff, 2014, 2016a; Tansel, 2017). It is thus necessary to critique neoliberalism not for its rhetorical promotion of free markets but instead for seeking to orchestrate societies in coercive, non-democratic and unequal ways (see also Beck \& Germann and Wigger in this special issue).

Crucially, such societal orchestration has states and households, together, at its heart. Below, we utilize the insights of feminist political economy scholarship to argue that the remaking of households in a manner which denies social justice is as important to neoliberalism as is the remaking of states in an anti-democratic manner. ${ }^{2}$ The centrality of households to capitalism is of course a long-standing concern of feminist scholarship (Dalla Costa and James, 1975; Mies, 1986; Benería \& Feldman, 1992), yet dominant modes of feminist analysis of neoliberalism while still important - tend to detach 'households', 'states' and 'markets' into discrete categories (Bakker \& Gill, 2003; Walby, 2009; Fraser, 2013). This article advocates a more integral approach, as outlined by authors such as Peterson (2010), Federici (2012), Roberts 
(2013), and Soederberg (2018). To be clear, these scholars focus on neoliberalism in practice, but their work informs this article's literary-theoretical analysis of neoliberal thought.

The paper is structured as follows. The next section offers a brief and critical review of the existing literatures on neoliberalism; subsequently, we outline our literary-theoretical approach, which discusses the roles of authorship, framing gestures, and foundational assumptions. Next, using canonical contributions by Friedrich Hayek and Milton Friedman as exemplars of neoliberal thought more broadly, our reading shows how both authors utilize techniques of characterization and constructions of epistemological legitimacy to make their case for a science of economics. We then argue that this matters because of how it masks their strong reliance on the remaking of states and households in highly specific ways. ${ }^{3}$ The paper concludes with some comments on the 'in principle' and 'real world' implications of our analysis.

\section{Taking for Granted Neoliberalism's Utopian Vision}

The dominant approach within the literatures is that neoliberalism's genesis in the midtwentieth century - in an era characterized by the growing role in capitalism for 'non-market' domains such as the state, trade unions, and welfare programmes - meant that from the beginning its worldview covered all areas of social life. Inextricably bound up with this worldview, however, was the recognition that such domains could not be eliminated or drastically reduced in scope and power overnight. Therefore, a common denominator across various literatures on neoliberalism is that, from its originary moments onwards, it has been a profoundly contradictory project of social transformation. On the one hand, there is a 'utopian vision of a free society and free economy' (Peck, 2010, p. 7); on the other hand, this vision transmutes 'into various arguments for the existence of a strong state as both producer and guarantor of a stable market society' (Mirowski, 2013, p. 54). Examples of the latter include vigilance against 'distortions' of the market by groups such as trade unions, and the maintenance of 'law and order' in times of economic crisis and/or protests against a smaller economic and social role for the state.

Consequently, discussions of neoliberalism have focused on 'actually existing neoliberalism' (cf. Brenner \& Theodore, 2002), and for two main reasons. One, the scope for 'market-oriented' political rule to exist in a variety of forms has turned out to be very significant, meaning that the possibilities for empirical studies of uneven, messy processes of 
neoliberalization have proved almost endless. Two, by enhancing our understanding of neoliberalism in empirically rich ways, the literatures also provide the basis for a critique of neoliberalism's utopian vision, especially its fundamental unrealizability. Consequently, debates and controversies have revolved around what are the putative essences of neoliberalization, which in turn inform how neoliberalism should be critiqued: a class project (Harvey, 2005), a drive to subordinate society to the market (Mirowski, 2013), an ongoing process of market-oriented regulatory restructuring (Peck, 2010), an anti-democratic political rationality (Brown, 2015), a discourse latent with transformative violence (Springer, 2016).

Clearly, our understanding of neoliberalism is more sophisticated than in the past - for example, in suggesting ways of overcoming unhelpful dichotomies such as state/market, which imply or actually propose essences that are intrinsic to various societal domains (cf. Bruff, 2011). However, the closest one gets to enquiring into, rather than taking for granted, neoliberalism's rhetorically 'pure' claims about free markets is to argue that the effects of seeking to realize the utopian vision is to empower the state in new ways, promote dedemocratization and economization, and so on. Hence, the possibility that neoliberal thought pays as much attention to 'non-market' domains as neoliberalism in practice has not been adequately explored (cf. Bruff, 2016b).

Furthermore, and importantly, there is often the absence in the literatures of 'non-market' domains that are not 'public' societal sites such as the state, which has implications for the study of neoliberal thought and practice. ${ }^{4}$ Some contributions have been helpful for showing that the so-called 'return of the state' after 2008 and the emergence of various forms of ostensibly antineoliberal populism do little to reverse the neoliberal tide that has been incoming since the 1970s, not least because the state never went away (Konings, 2012; Jessop, 2013; Davies, 2014). However, 'public' societal sites are heavily prioritized, skewing analysis and critique towards questions of state power and political authority. As noted in the introduction, there is a long tradition of feminist political economy work on the centrality of households to capitalism, and there has been much recent research on neoliberalism as well (see also Harcourt, 2017). The integral approach advocated by this article not only has analytical benefits, i.e. for gaining a richer understanding of the texts discussed below and thus of neoliberalism in thought and in practice. It also, as we consider briefly in the conclusion, enables us to acknowledge that households are central to resistance to neoliberalism as well as to the neoliberal worldview itself (cf. Bruff \& Wöhl, 2016).

The question, then, is how to enquire into the possibility that neoliberal thought pays just as much attention to 'non-market' domains, such as states and households, as neoliberalism in 
practice. In our view, this necessitates the literary-theoretical approach discussed next, which enables us to explore carefully the practices of writing these texts and thus the means by which the texts are produced.

\section{Authoring Texts through Framing Gestures}

The approach we outline below facilitates a thorough interrogation of the forms taken by the argument, the narrative techniques deployed, and the modes of articulation present in and across neoliberal texts. In particular, we are interested in understanding the significance of foundational assumptions in texts viewed as canonical contributions to neoliberal thought: if 'some kind of assumptions (as to what we are thinking about) must be made before we can even begin to think' (Thompson, 1995, p. 48, emphasis in original), then it is incumbent upon us to focus on the texts where such assumptions are most likely to be visible. It does not follow that they are explicated in clear and systematic ways, but it is essential that they are identified and analyzed - the qualities of texts deemed canonical become the qualities looked for in texts which are produced subsequently (Harries, 2001, p.45).

We propose to treat canonical neoliberal texts as literary endeavours: how they are written is as important to critical enquiry as their content. As Starnes (2016, p. 156) explains, subtle gestures within the text reiterate foundational assumptions as uncontroversial to the extent that they become ontological features, no longer available as grounds for debate or critique. Recognizing how this happens requires making seemingly familiar ways of writing unfamiliar, and looking as much at how authors write as at what they write - for example, how authors construct themselves as experts and position their texts within disciplinary literatures (see also Starnes, 2018). As a result, we view the authoring of texts as a creative and productive process. This does not mean that we subscribe to a traditional understanding, i.e. that authors are singular, unique and self-possessed creators of the texts published in their name, somehow working in isolation from the 'socio-historical conditions within which a writer exists' (Morton, 2003, p. 30; cf. Gramsci, 1985). Instead, we find useful Walter Benjamin's (1970 [1934]) exploration of how authors are implicated in the process of producing texts beyond those they themselves author, through what he refers to as 'techniques of production.' Benjamin advocates treating texts as literary artefacts, which requires examining not just content, but also literary 
technique, or the processes that show how content and form are entwined in all modes of writing (pp. 87-88).

Hence, we emphasize the role and position of the 'expert' within the text under consideration. This shapes the production of knowledge and the conditions for critique of that knowledge - and thus production of future knowledge. It also enables us to examine how these techniques of literary production are enacted within a text: for example, where authors either implicitly or explicitly comment on the writing process within the text. Such framing gestures have a specific role in the constitution of the 'rules' of epistemological legitimacy, which shape the conditions of possibility for future contributions to the field and thus for critique of the 'expert' who helped create or contribute to the field in the first place.

In order to illustrate the advantages of the approach outlined above, we examine 'The Use of Knowledge in Society' (Hayek, 1948a; originally published in 1945) and 'The Methodology of Positive Economics' (Friedman, 1953a). Both papers have, since their publication, been understood as seminal contributions - they have been cited thousands of times each, and also serve as the philosophical foundations for Hayek and Friedman's broader intellectual and political agendas. As such, they are highly appropriate texts for the purposes of this article. In exploring the texts, we looked at how the framing gestures employed by Hayek and Friedman allow them to produce a specific image of the science of economics as an enterprise that takes the study of free markets as its raison d'etre. However, this apparently natural equation between science and markets is in fact a technique of authorship which obscures the simultaneous constitution of specific, submerged images of states and households in the same text. This 'forgetting' may be unintentional, often blending into the assertive practices of academic writing in which authors make space for their text in the literature by referring to their role as an expert, or not acknowledging the fully contestable nature of the decisions they make. Nevertheless, it is clear that, by virtue of their treatment of the question of a putative science of economics as one resolved by the image of the market, Hayek and Friedman propose the market as naturally occurring while themselves participating in its constitution.

But how do they actually go about this task? As we explain in the next section, both authors follow a similar line of argument. Firstly, they proclaim a scepticism about the possibilities for a science of economics, a scepticism which derives from the scientific method itself. Secondly, they use this proclamation to state that their own contribution is modest, because it recognizes the fallibilities inherent to all knowledge claims. Thirdly, they make a proposal which comprises an alternative understanding of markets in capitalism compared to what they claim to be the dominant view. Fourthly and finally, they use their avowed scepticism and modesty 
to defend their proposal against possible criticism on the grounds that such criticism is unscientific, thereby foreclosing critique in the process. Therefore, in a creative and authorially distinctive manner, Hayek and Friedman's framing gestures delegitimize critiques of their position as unscientific and thus inadmissible arguments, leaving the way clear for a naturally occurring market to represent the 'normal' way to understand their contribution to science. While this argument may not seem unfamiliar, the literary-theoretical approach outlined above reveals what is masked by such gestures, helping form the basis of a more appropriate critique of neoliberalism. ${ }^{5}$

\section{Hayek and Friedman: Scepticism, Modesty, Proposal, Foreclosure}

Both texts under consideration focus on the possibilities of creating a science of economics. Hayek discusses the problems of scientific knowledge (for example, 1948a, pp. 79-81), whereas Friedman's essay is 'concerned primarily with certain methodological problems that arise in constructing the "distinct positive science"" Keynes called for (1953a, p. 3). Nevertheless, while ostensibly about scientific methods, these texts also engage with ontological themes concerning the science of economics' object of study and epistemological questions regarding the kinds of knowledge production which are deemed admissible by both authors.

This reading of Hayek in particular may prove unusual, because it demonstrates his preoccupation with direct observation and thus empiricism - famously, he disagreed with Karl Popper on the supposed unity of the scientific method and thus the possibilities for universal knowledge claims. Hayek begins by stating that 'knowledge of the circumstances of which we must make use never exists in concentrated or integrated form, but solely as the dispersed bits of incomplete and frequently contradictory knowledge which all the separate individuals possess' (1948a, p. 77). This lies at the heart of his science of economics: while accounting for differences between the natural and social sciences, Hayek nevertheless frames these dissimilarities not as the limits of the scientific method but instead as an ontological premise regarding who in society is most likely to have appropriate forms of knowledge of societal circumstances. Hence, his scepticism about the possibility of creating a science of economics focuses on questioning the scientific status of supposed experts, primarily because even their knowledge of the world is particular rather than universal (p. 80). 
This means that Hayek's critique does not reject a science of economics, but merely dismisses the possibility for generalizable conclusions to underpin decision-making; he is not as different from Popper as is usually assumed. Consequently, he questions the possibility of anyone being expert enough to plan or manage economies on epistemological grounds of modesty: we can produce knowledge about our circumstances only via our own direct observation of them. Hayek thus argues that planning can successfully be undertaken only by those able to observe directly the 'relevant changes and the resources immediately available to meet them' (p. 84). Ultimately it is the problem of representation which troubles Hayek, not science itself. He therefore advocates a kind of extreme empiricism in which decisions must only be based on that which is directly observable and undistorted by the knowledge held by others (for example, experts).

It is at this point that Hayek's position becomes more problematic. By entering into the act of writing in order to proclaim his scepticism about the knowledge claims of others and to affect a commitment to epistemological modesty, Hayek implicitly frames himself as an expert. This leaves him apparently exempt from the problems inherent to representation of knowledge and thus allows him to act as the arbiter of what counts (relative importance of particular things with which the 'man on the ground' is concerned) and what does not (the wider conditions and context for this 'economic calculus'). Therefore, when Hayek then proposes the price system in competitive markets as a solution to the impossibility of full and empirically verifiable knowledge in the hands of individual humans (pp. 85-86), he endorses the impersonal market as a mechanism for the aggregation of particular knowledges born out of individuals' direct observation of prices.

By making the proposal in this way, Hayek's position as expert becomes clear: only through his understanding of science can it be possible to appreciate markets in the appropriate manner. For example, he describes the price mechanism as a 'marvel' on the basis of its accuracy in spite of being free from deliberate human design (p. 87). He then argues that the price mechanism has been stumbled upon, rather than constituted through human practices. Hayek thus treats it as an ontological fact, failing to acknowledge his own role in its reiteration and claiming he cannot possibly have the 'expert' knowledge to view it completely. This forgets, of course, the constitution of Hayek as just such an expert, qualified to choose those examples, plus his concomitant role in constituting the price mechanism's status as 'accurate'. Consequently, the proposal falls foul of Hayek's self-proclaimed scepticism and modesty, because he engages explicitly in the kind of representation of knowledge that, earlier in the paper, he inveighed against forcefully. 
What is Hayek doing, then? We argue that he frames an 'appropriate' science of economics as possible only if that science understands markets as the singular legitimate source of human knowledge and activity - he forecloses critique of his own position as, by default, unscientific. By declaring that markets have spontaneously emerged over time free from human interference, Hayek posits them as ontological facts rather than as images constituted by his own literary techniques. Hence, the marvel of the market is depoliticized via Hayek discounting his own political decisions about what is relevant and what is not for a science of economics to be credible. For example, his claim that the price mechanism is indispensable for rational calculation in the face of economic complexity even goes so far as to explicitly deny the politics in its constitution and thus to dismiss critiques on political grounds (p. 89). Hayek then explains that the 'remaining dissent [from other economists] seems clearly to be due to purely intellectual, and more particularly methodological differences' (p. 89, added emphasis). The final passages in the article are devoted to debunking just one such critique (which is derisorily dismissed) and reinforces further Hayek's extreme empiricism, which he attributes to 'the unavoidable imperfection of man's knowledge and the consequent need for a process [i.e. the market] by which knowledge is constantly communicated and acquired' (p. 91).

To summarize, while Hayek can be (and indeed is often) read as critiquing the possibilities of constructing an 'objective' science of economics, he is in fact himself depoliticizing and stripping out the possibility of subjective bias within economics (knowingly or not). He does this by arguing that the only legitimate knowledge is not that which acknowledges the possibility of political expression, bias or questions of perspective in its representation, but that which is directly observed. In order to make this argument, Hayek rests on a partial and inherently political constitution of the market mechanism as ontological, neutral and, crucially, exempt from critique on 'unscientific' political grounds. Furthermore, by claiming only a methodological purpose for his text, Hayek obscures the epistemological and ontological claims his text establishes, immunizing them from (delegitimized) critique and framing future discussion of his argument around how markets function rather than the means by which he makes these claims about markets in the first place.

We have already noted that Hayek's disagreements with Popper on the nature and status of scientific knowledge is significantly over-played. The same can be said about the differences between the 'Austrian' and 'Chicago' schools of neoliberal thought - Hayek being associated with the former, Friedman with the latter. While it is clear that distinctions can be drawn (cf. Kirzner, 1997) - for example, the potential for individuals to have full information about their circumstances - an examination of Friedman's text reveals strong overlaps. For instance, 
Friedman begins with a discussion of the distinctions between what he terms positive (his preferred version) and normative economics. Through this, he acknowledges that even 'positive economics' analysis has normative relevance and implications, which, along with the nature of economics as explicitly concerned with humans, poses a challenge to the development of a science independent of ethical positions or normative judgements (p. 4). Among the obstacles to the generation of empirical evidence that will allow the positive science of economics to advance is language, which is used to construct hypotheses, categorize materials, and shape our understanding (p. 7). Ultimately, Friedman's scepticism revolves around the role that interpretation plays in the representational process of using language to shape and communicate any available empirical evidence.

This leads to the claim that "[s]elf-proclaimed "experts" speak with many voices and can hardly all be regarded as disinterested... "expert" opinion could hardly be accepted solely on faith even if the "experts" were nearly unanimous and clearly disinterested' (p. 4). Hence, Friedman forefronts his modesty in such matters, for he acknowledges the role of judgement in assessing competing knowledge claims. Moreover, he uses this epistemological restraint as the basis for an appeal to direct observation as a means of making such judgements. Empirical evidence is cited as the criteria by which arguments are accepted or rejected and, starkly, is 'alone' in being able to show whether analytical categories 'have a meaningful empirical counterpart.' (p. 7).

Hence, Friedman's argument proceeds along similar lines to Hayek's. Also with Hayek, it is at this stage that Friedman's argument becomes more difficult to sustain without damage being done to the principles embodied in the text's opening remarks. For example, he proposes that 'the only relevant test of the validity of a hypothesis is comparison of its predictions with experience' (pp. 8-9; original emphasis). While seemingly innocuous, this sets the stage for an extensive discussion of scientific procedure which delineates, in highly specific ways, acceptable and unacceptable forms of knowledge production. Friedman thus frames himself both as an expert in such matters and as someone who is somehow immune to the ethical and normative issues which he earlier argued were an inevitable part of all scientific research. This becomes more apparent when discussing the stages of constructing and testing hypotheses. Friedman acknowledges that the initial stage is always reliant on previous decisions, the context of old hypotheses, and is thus subject to the knowledge and interests of the investigator. Consequently, these 'two methodologically distinct stages [of construction and testing] are always proceeding jointly' (p. 14). He then claims, however, that the notion that starting assumptions are relevant to the validity of the hypothesis being tested is: 
fundamentally wrong and productive of much mischief. Far from providing an easier means for sifting valid from invalid hypotheses, it only confuses the issue, promotes misunderstanding about the significance of empirical evidence for economic theory, produces a misdirection of much intellectual effort devoted to the development of positive economics, and impedes the attainment of consensus on tentative hypotheses in positive economics (p. 14).

The implications emerge later in the text. Firstly, Friedman asserts that '[i]t is only a short step' from the discussion of scientific procedure to the - in his view, widely accepted - hypothesis that firms seek rationally to maximize profits and have full knowledge of the information needed to make such an attempt (p. 21). Moreover, while he acknowledges that evidence supporting such a hypothesis is hard to document, its failure to be contradicted is by default the evidence for its scientific worth. On the surface, this is an example of Friedman's commitment to scientific procedure, whereby a hypothesis remains accepted until it is proven to be false. Yet, later on, a more plausible reason appears. Here, via a series of assertions, dismissals and unsubstantiated claims, Friedman tackles attempts in existing scholarship to contradict this hypothesis. According to him, theories of imperfect or monopolistic competition - for which a wide range of empirical evidence is available, both then and now - possess 'none of the attributes that would make [them] a truly useful general theory' (p. 38). They are deficient, logically meaningless, offer no analytical tools, and therefore must be considered incompetent (pp. 38-9).

Why does Friedman treat alternative approaches and analyses with such contempt, especially when they appear to offer the possibility for precisely the kind of scientific dialogue that he calls for? For us, it is because he adopts a similar approach to Hayek. While Friedman's invocation of markets is more concrete and applied - considering questions of company strategy and inter-firm competition (or lack of) - compared to Hayek's more abstract claims about the price mechanism, the effect is remarkably alike. Hence, he also frames an 'appropriate' science of economics as possible only if that science understands markets as the singular legitimate source of human knowledge and activity - Friedman forecloses critique of his own position as, by default, unscientific. He does this via implicit ontological claims about the assumed rational actions of firms and thus, more broadly, about the markets the firms are part of; epistemologically, he asserts that any deviation from the process of hypothesis testing as outlined in the text renders that piece of research irrelevant. Hence his concluding argument 
that normative judgements 'impede objectivity' and thus the formulation of scientifically informed analysis (p. 40), which can be understood as an attempt to delegitimize alternative worldviews (be they on the nature of firms and markets or on the principles governing research). It is clear that, contrary to the pretensions offered early in the text, Friedman understands himself as an expert, and an expert whose judgement is superior to those within economics who believe that normative questions are relevant in a range of ways.

To summarize, while Friedman can be (and indeed is often) read as defending an objective, value-free version of social science research, he in fact saturates his arguments about science with his own value-laden assertions (knowingly or not). He acknowledges the inevitability of normative influences and ethical implications of the analytical judgements that are made, but ignores his own self-interest when arguing that the influence of interests and the difficulty of accuracy in starting assumptions and representations is of no consequence for a science of economics to be 'good'. In order to make this argument, Friedman ultimately rests on a partial and inherently political constitution of the market which he defends as ontological, neutral and exempt from 'incompetent' and unscientific critique. Furthermore, as with Hayek the text obscures these epistemological and ontological claims, immunizing them from (delegitimized) critique and framing future discussion of the argument around how to study markets scientifically rather than the means by which the scientific study of markets is valorized in the first place.

\section{Hayek and Friedman: Remaking States and Households in the Name of Free Markets}

As argued in the previous section, Hayek and Friedman use a range of author framing gestures in order to set the scene for the promotion of the free market as the ideal principle for organizing society. More specifically, they do so via a scepticism-modesty-proposal-foreclosure sequence which seeks simultaneously to entwine a science of economics with the valorization of free markets and to prevent critiques of their approach from untangling science from free markets. It is therefore unsurprising that (as noted above) critical engagements with neoliberalism have focused on how the abstract formalism of a science of free markets has yet to be realized in practice, with state empowerment, de-democratization and economization being the more likely 
outcomes. Yet this leaves outside the scope of critical analysis the foundational assumptions which underpin the putative science of free markets. It is to these that we now turn.

Hayek and Friedman's defence of a science of free markets leads them, in other works, to focus on how the 'real economy' should/could move closer to the abstract ideal of the market. This is often discussed in terms of distortions or obstacles which need eliminating - for example, trade union power and discretionary state intervention. On the surface, these are standard neoliberal claims about undesirable interference in potentially 'pure' market processes, meaning that the texts appear to be arguments for negation - that is, for the need to remove the artificial poison from the naturally occurring market. In contrast, we contend that a rather different case is being made: the texts argue for specific kinds of states and households per se rather than position them as obstacles on the road to market utopia. Hence, while neoliberal intellectuals valorize the free market as an abstract ideal, the crucial passages in their texts are those which discuss the sites in society - principally, states and households - which require remaking in the name of free markets. It is the apparent expulsion of states and households from markets which forces these texts into a strong dependence on states and households in order to make markets possible; without states and households, markets in capitalism have no foundation upon which they can be constructed and perpetuate.

To illustrate, we start by considering essays published in the same volumes as the 'science' texts. Hayek's 'The Economic Conditions of Interstate Federalism' (Hayek, 1948b) begins by stating that 'the main purpose of interstate federation is to secure peace' across borders (p. 255), between different individual nation-states as part of a larger political union. However, within a few pages he clarifies that the main means of achieving this is to create an economic union: otherwise, 'conflicts of interests tend to become conflicts between the same [national] groups of people, instead of conflicts between groups of constantly varying composition' (p. 257). As such, Hayek recommends a single, federation-wide monetary policy, the absence of tariffs within the union, and bans on state assistance for certain industries. The means of achieving these goals comes later in the text: the 'federation will have to possess the negative power of preventing individual states from interfering with economic activity...there must be no substitution of day-to-day interference and regulation for the impersonal forces of the market' (p. 267, p. 268; emphasis added). Hence, through the federation 'providing a rational permanent framework' (p. 268; emphasis added) which insulates national states from popular participation in political life, Hayek attacks the idea of democracy itself, arguing that democracy 'will work only if we do not overload it' (p. 271). In other words, economic union can be achieved only by the proactive, perpetual remaking of states in an anti-democratic manner. 
In 'The "Welfare" Effects of an Income Tax and an Excise Tax' (Friedman, 1953b), Friedman critiques the 'alleged' superiority of income compared to excise taxes in terms of the welfare outcomes they generate (p. 100). He discusses the effects of income and excise taxes on indifference curves - which are used in mainstream economics to model consumption preferences for given individuals and communities - to argue that the latter in fact have superior welfare effects than the former. However, as with Hayek the implications come later: Friedman builds on his analysis to argue explicitly against progressive income taxation - used by governments to reduce levels of socio-economic inequality - because it is likely to 'falsify [i.e. render inefficient] rates of substitution' of one good for another by members of the community when altering their consumption preferences (p. 112). Hence, through the claim that debates on taxation should be about potential allocative efficiency rather than putative distributional outcomes (p. 107), Friedman contends that the only optimal form of taxation is that which looks like an excise tax - levied on all members of the community at the same level (pp. 112-113). A key implication is that individuals and thus households (which are taken to be the same thing) ought to be held responsible for the waxing and waning of general economic fortunes - for example, if they consume in a sub-optimal manner - and not societal factors such as axes of inequality (for more on this, see Bruff, 2018). When economic difficulties ensue, households thus need to bear the burden of adjustment towards an optimal use of resources, becoming more accurate in estimating future income and forming more appropriate consumption preferences. In other words, economic efficiency can be achieved only by the proactive, perpetual remaking of households in a manner which denies social justice.

Space prevents a more detailed discussion of these texts, but it is instructive to connect them to other canonical works authored by Hayek and Friedman, which can also be read and critiqued in the literary-theoretical manner outlined in this article. For instance, Hayek's (1941) The Pure Theory of Capital argues in detail that markets are inherently dynamic, meaning that the future is unknown and no market participant has full knowledge of their situation as a result. Nevertheless, he still contends that a tendential state of equilibrium and order in the economy is possible, but only if the market can operate unhindered by non-market forces (for more on this, see Bruff, 2018). Towards the end of the book - which is ostensibly a critique of neoclassical forms of economics such as Friedman's - Hayek makes clear that the main obstacles to markets operating in this fluid and dynamically ordered way are monopolies as operated by trade unions and especially the state. Strikingly, private monopolies (i.e. by a dominant firm) are conspicuous by their absence, presumably because Hayek would claim that market processes would erode them naturally over time; hence, states need to be self- 
constraining, non-monopolistic entities in order to facilitate the unhindered market. Moreover, in The Constitution of Liberty (1960) Hayek outlines an expanded conception of legitimate state coercion - which is legitimate insofar as it performs the anti-democratic duties discussed above - and discusses at length welfare states and progressive taxation, which are criticized heavily as illegitimate forms of coercion because they prevent individuals and households from being responsible for general economic outcomes.

Regarding Friedman, A Theory of the Consumption Function (1957) outlined his famous Permanent Income Hypothesis (PIH). The PIH argues that individuals plan over the whole life cycle their expected incomes and therefore consumption patterns - for instance, if they foresee career progression which leads to a gradually increasing salary. However, this argument coheres only via the assumption that savings and income levels are unrelated phenomena; that is, a poor individual's savings decisions are as unconstrained by material circumstances as a rich individual's. As such, Friedman assumes inequality is not a factor in savings and consumption patterns, for they are borne out of individual life cycle calculations. A key implication is the conclusion (p. 234) that rising permanent income expectations are more economically optimal if they result from individuals investing in their own future rather than the outcome of external stimulus (for example, state spending in response to a recession). In other words, Friedman attacks the notion of state borrowing, but endorses personal borrowing; households ought to be remade as indebted societal sites, with clear implications for the reproduction of various axes of inequality. Moreover, as with Hayek the remaking of states as self-constraining entities emerges as a key goal, in the name of free markets, so they do not provide the external stimulus which distorts and undermines individual life cycle calculations. This is also the underlying rationale for the mammoth A Monetary History of the United States, 1867-1960 (Friedman and Schwartz, 1963); indeed, it is striking that, for someone who is rhetorically hostile to the state, Friedman managed to co-author almost 1000 pages on how precisely the state should have acted in the sphere of monetary policy over the course of a century.

It is hopefully clear that the texts discussed in this article ought to be understood not just for what is written in them, but also for how they are written. This enables us to acknowledge how Hayek and Friedman utilize literary techniques of production in the attempt to constrain and limit the available grounds for critique of their position. Moreover, our analysis facilitates the decisive rejection of the notion that neoliberal texts are fundamentally about the valorization of free markets, because we can now recognize instead that they (re)produce highly specific images of states and households in service to the abstract principle of the free market. States 
and households need to be at the heart of analyses of neoliberalism, and thus of critiques of it in theory and in practice.

\section{Conclusion}

Via a literary-theoretical approach to the reading of texts, this article has argued that neoliberal thought can be productively re-examined in order to bring something new to discussions of canonical texts in this tradition and also to debates and controversies about contemporary forms of neoliberalism. Utilizing Friedman and Hayek as exemplars, we have argued that their explicit project - the construction of a science of free markets - has served to mask an implicit yet more important agenda - the remaking of states and households. As such, we contend that it is time for critiques of neoliberalism to move beyond the 'pure' theory / 'messy' practices dichotomy, as productive as this has been over the last two decades. Instead, we ought to understand neoliberalism as the attempt to orchestrate societies in coercive, non-democratic and unequal ways. Furthermore, this attempt is not somehow an effect of projects to realize the vision of a free market utopia; it is the project itself.

It was noted earlier in the article that neoliberalism's genesis in the mid-twentieth century in an era characterized by the growing role in capitalism for 'non-market' domains such as the state, trade unions, and welfare programmes - meant that from the beginning there was a recognition that such domains could not be eliminated or drastically reduced in scope and power overnight. For this reason, it is essential that we understand the current period of authoritarian neoliberalism as actually closer to the neoliberal vision than in the past. States are reconfiguring into increasingly authoritarian entities or are expanding already-existing forms of authoritarian practices, households have become increasingly weighed down by indebtedness, the expulsion of the poor and vulnerable from social programmes supposed to help them has become gradually normalized, and the 'solutions' on offer to continued low or non-existent economic growth - which frequently invoke the fiction of the 'free market' - are strongly reminiscent of the processes (such as the securitization of financial instruments) which catalyzed the emergence of serious crises in the late 2000s.

The analytical implications of our argument are hopefully clear by now. Regarding the implications for resisting neoliberalism on the basis of the critique that we offer, it is hoped that this article speaks to the growing recognition that the state is imbricated in and not protective 
against neoliberal practices. This might, in the longer-term, create more propitious conditions for the emergence of new, more equitable modes of living via a greater awareness of what needs to change (Bruff, 2016a). However, this is only possible if we engage in and also look beyond formal forms of politics and activism, towards households as being a potentially crucial site of politicization which 'provide[s] leverage for radical social critique' (Young, 2005, p. 146; see also Federici, 2012; Dowling, 2016). In other words, if the great power of the neoliberal project has been the attempted remaking of states and households in the name of the market, then what happens if we pursue an alternative endeavour, seeking to remake states and households in the name of equality, justice, dignity and solidarity?

\section{Acknowledgements}

Previous versions of the article were presented at the 2017 conferences organized by the European Sociological Association in Athens and the European International Studies Association in Barcelona. Additionally, preliminary forms of the argument were presented as seminar talks in 2017 at the universities of Manchester and Nottingham. Many thanks to all of those who asked questions and provided feedback, especially Cemal Burak Tansel, and to the referees for their useful comments and suggestions.

\section{Disclosure Statement}

No potential conflict of interest was reported by the authors.

\section{References}

Bakker, I. \& Gill, S. (eds) (2003). Power, production and social reproduction: Human in/security in the global political economy. Basingstoke: Palgrave Macmillan.

Benería, L. \& Feldman, S. (eds) (1992). Unequal burden: Economic crisis, persistent poverty, and women's work. Boulder: Westview.

Benjamin, W. (1970). The author as producer. New Left Review, 1(62), 83-96. 
Bruff \& Starnes - Framing the Neoliberal Canon

Brenner, N., \& Theodore, N. (2002). Cities and the geographies of 'actually existing neoliberalism'. Antipode, 34(3), 349-379.

Brown, W. (2015). Undoing the demos: Neoliberalism's stealth revolution. New York: Zone Books.

Bruff, I. (2011). Overcoming the state/market dichotomy. In S. Shields, I. Bruff, \& H. Macartney (Eds.), Critical International Political Economy: Dialogue, debate and dissensus (pp. 80-98). Basingstoke: Palgrave Macmillan.

Bruff, I. (2014). The rise of authoritarian neoliberalism. Rethinking Marxism, 26(1), 113-129.

Bruff, I. (2016a). Authoritarian neoliberalism and the myth of 'free markets'. ROAR, 4, 14-27.

Bruff, I. (2016b). Neoliberalism and authoritarianism. In S. Springer, K. Birch, \& J. MacLeavy (Eds.), The handbook of neoliberalism (pp. 107-117). New York: Routledge.

Bruff, I. (2018). Overcoming the allure of neoliberalism's market myth. Currently unpublished manuscript.

Bruff, I., \& Wöhl, S. (2016). Constitutionalizing austerity, disciplining the household: Masculine norms of competitiveness and the crisis of social reproduction in the Eurozone. In A. Hozić \& J. True (Eds.), Scandalous economics: Gender and the politics of financial crises (pp. 92-108). Oxford: Oxford University Press.

Cahill, D. (2014). The end of laissez-faire? On the durability of embedded neoliberalism. Cheltenham: Edward Elgar.

Cooper, M. (2017). Family values: Between neoliberalism and the new social conservatism. New York: Zone Books.

Dalla Costa, M. \& James, S. (1975). The power of women and the subversion of the community. Bristol: Falling Wall Press.

Davies, W. (2014). The limits of neoliberalism: Authority, sovereignty and the logic of competition. London: Sage.

Dowling, E. (2016). Valorised but not valued? Affective remuneration, social reproduction and feminist politics beyond the crisis. British Politics, 11(4), 452-468.

Federici, S. (2012). Revolution at point zero: Housework, reproduction, and feminist struggle. Oakland: PM Press.

Fraser, N. (2013). Fortunes of feminism: From state-managed capitalism to neoliberal crisis. London: Verso.

Friedman, M. (1953a). The methodology of positive economics. In M. Friedman, Essays in positive economics (pp. 3-43). Chicago: University of Chicago Press. 
Bruff \& Starnes - Framing the Neoliberal Canon

Friedman, M. (1953b). The 'welfare' effects of an income tax and an excise tax. In M. Friedman, Essays in positive economics (pp. 100-113). Chicago: University of Chicago Press.

Friedman, M. (1957). A theory of the consumption function. Princeton: Princeton University Press.

Friedman, M. (1962). Capitalism and freedom. Chicago: University of Chicago Press.

Friedman, M., \& Schwartz, A. J. (1963). A monetary history of the United States, 1867-1960. Princeton: Princeton University Press.

Gramsci, A. (1985). Selections from cultural writings (Eds. D. Forgacs \& G. Nowell-Smith; Trs. W. Boelhower). London: Lawrence and Wishart.

Harcourt, W. (2017). Bodies in resistance: Conversations on gender, body politics and authoritarian neoliberalism. In C. B. Tansel (Ed.), States of discipline: Authoritarian neoliberalism and the contested reproduction of capitalist order (pp. 67-86). London: Rowman \& Littlefield International

Harries, E. W. (2001) Twice upon a time: Women writers and the history of the fairy tale. Princeton: Princeton University Press.

Harvey, D. (2005). A brief history of neoliberalism. Oxford: Oxford University Press.

Hayek, F. A. (1941). The pure theory of capital. London: Macmillan.

Hayek, F. A. (1944). The road to serfdom. Chicago: University of Chicago Press.

Hayek, F. A. (1948a). The use of knowledge in society. In F. A. Hayek, Individualism and economic order (pp. 77-91). Chicago: University of Chicago Press.

Hayek, F. A. (1948b). The economic conditions of interstate federalism. In F. A. Hayek, Individualism and economic order (pp. 255-272). Chicago: University of Chicago Press

Hayek, F. A. (1960). The constitution of liberty. Chicago: University of Chicago Press.

Jessop, B. (2013). Putting neoliberalism in its time and place: A response to the debate. Social Anthropology, 21(1), 65-74.

Kirzner, I. M. (1997). Entrepreneurial discovery and the competitive market process: An Austrian approach. Journal of Economic Literature, 35(1), 60-85.

Koch, I. (2018). From welfare to lawfare: Environmental suffering, neighbour disputes and the law in UK social housing. Critique of Anthropology, 38(2), 221-235.

Konings, M. (2012). Imagined double movements: Progressive thought and the specter of neoliberal populism. Globalizations, 9(4), 609-622.

Mies, M. (1986). Patriarchy and accumulation on a world scale: Women in the international division of labour. London: Zed. 
Bruff \& Starnes - Framing the Neoliberal Canon

Mirowski, P. (2013). Never let a serious crisis go to waste: How neoliberalism survived the financial meltdown. London: Verso.

Morton, A. D. (2003). The social function of Carlos Fuentes: A critical intellectual or in the 'shadow of the state'? Bulletin of Latin American Research, 22(1), 27-51.

Peck, J. (2010). Constructions of neoliberal reason. Oxford: Oxford University Press.

Peterson, V. S. (2010). Global householding amid global crises. Politics \& Gender, 6(2), 271281.

Roberts, A. (2013). Financing social reproduction: The gendered relations of debt and mortgage finance in twenty-first century America. New Political Economy, 18(1), 21-42.

Soederberg, S. (2018). Evictions: A global capitalist phenomenon. Development \& Change, 'Early View' section.

Springer, S. (2016). The discourse of neoliberalism: An anatomy of a powerful idea. London: Rowman \& Littlefield International.

Starnes, K. (2016). Fairy tales and International Relations: A folklorist reading of International Relations textbooks. London: Routledge.

Starnes, K. (2018). Author framing in International Relations: Understanding writing as disciplining political practice. Currently unpublished manuscript.

Tansel, C. B. (2017). Authoritarian neoliberalism: Towards a new research agenda. In C. B. Tansel (Ed.), States of discipline: Authoritarian neoliberalism and the contested reproduction of capitalist order (pp. 1-28). London: Rowman \& Littlefield International.

Thompson, E. P. (1995). The poverty of theory: Or an orrery of errors (new ed.). London: Merlin Press.

Walby, S. (2009). Globalizing inequalities: Complexity and contested modernities. London: Sage.

Watson, M. (2017). Rousseau's Crusoe myth: The unlikely provenance of the neoclassical homo economicus. Journal of Cultural Economy, 10(1), 81-96.

Young, I. M. (2005). House and home: Feminist variations on a theme. In I. M. Young, On female body experience: 'Throwing like a girl' and other essays (pp. 123-154). Oxford: Oxford University Press. 


\title{
Notes on contributors
}

Ian Bruff is Lecturer in European Politics at the University of Manchester, UK. He has published widely on capitalist diversity, European capitalisms, neoliberalism, and social theory. He is currently researching the foundations of neoliberal thought, and is the Managing Editor of the Transforming Capitalism book series published by Rowman \& Littlefield International.

Kathryn Starnes is Lecturer in International Relations at Manchester Metropolitan University, UK. She is currently researching IR narratives via postcolonial approaches to Gothic literature to explore practices of epistemic violence. She has published Fairy Tales and International Relations: A Folklorist Reading of IR Textbooks (Routledge, 2017).

\begin{abstract}
Notes
${ }^{1}$ Synonymic terms such as 'competitive markets' or simply 'the market' perform the same function as 'free markets' in neoliberal texts. As noted in the section 'Remaking states and households' in this article, neoliberal texts make their claims about 'free markets' in terms of negation - i.e. the need to eliminate undesirable interference in otherwise naturally occurring market processes. As such, the function performed by the literary device 'free markets' extends to similar terms invoked to make the same points about negating unnatural interferences. See also Bruff (2018).

${ }^{2}$ An ostensibly similar argument has been made by Melinda Cooper. However, there are two key differences between her and our position: (i) Cooper argues that during the 1960s and 1970s neoliberal intellectuals 'refined and in some cases utterly revised their founding concepts' in response to various social upheavals (2017, p. 18), which skips over the canonical works we consider of such importance for neoliberalism's subsequent trajectory; (ii) while she is correct to point to the growing political alliance between (economic) neoliberalism and (social) neoconservatism from the 1970s onwards, the intellectual and philosophical basis for such an alliance had always been immanent to neoliberalism (as this article shows).

${ }^{3}$ For reasons of space, this article does not address the ordoliberal strand of neoliberal thought. Nevertheless, the argument found in this article implicitly addresses a key thread within literatures on neoliberalism, namely ordoliberalism's possible incompatibilities with the Austrian and Chicago forms of neoliberalism due to its explicit recognition of the state's role in the constitution and functioning of markets. It is hopefully clear that, rather than asking whether ordoliberalism can be considered neoliberal or not, we ought to acknowledge that all significant strands of neoliberal thought envision crucial roles for states and households in the constitution of markets in capitalism. Ordoliberals are simply more explicit about states in particular compared to scholars such as Hayek and Friedman.

${ }^{4}$ This includes the work of one of us, who has written extensively on neoliberalism. For instance, Bruff (2014) discusses 'social' institutions of governance such as collective bargaining in the workplace, political parties and welfare states, all of which could be understood as 'public' societal sites. While these institutions often have dense and multi-faceted connections with 'private' sites such as households - especially regarding workfarism - it is only more recently that an explicit discussion of households became visible in his work (Bruff and Wöhl, 2016). Nevertheless, the argument in the 2014 article 'nonmarket areas of social life took on a particularly important role in neoliberal ideology' (p. 114)
\end{abstract}


facilitated the extension of the initial discussion to households. See also Koch (2018) on state coercion and localized forms of social struggle, especially around housing.

${ }^{5}$ The reader will start to notice the repetition of a few key phrases and points. This is deliberate, for it maximizes the potential of our focus on the articulation and organization of language in neoliberal texts. It also permits the use of repetition in our own articulation and organization of language, as a means of showing what the implications are of our interrogation of neoliberal texts. 